\title{
Why Should SLT be the First-Choice Treatment for Glaucoma?
}

\author{
Mina Abdelmseih* \\ Department of Ophthalmology, Augenärzte am Meer Clinic, Germany
}

Submission: July 21, 2017; Published: August 11, 2017

*Corresponding author: Mina Abdelmseih, Department of Ophthalmology, Augenärzte am Meer Clinic, Germany, Email: dr.mina.abdelmseih@gmail.com

\section{Abstract}

Glaucoma is a heterogeneous group of optic neuropathy characterized by damage to the optic nerve and visual-field damage. It is one of the most common causes of irreversible blindness worldwide. Early diagnosis and management are critical to prevent irreversible loss of vision. SLT as primary treatment is a safe and effective procedure in various types of glaucoma, including primary open-angle glaucoma (POAG), Ocular Hypertension, normal-tension glaucoma (NTG), pseudoexfoliation glaucoma (PXFG), steroid-induced glaucoma.

Keywords: Glaucoma; Selective laser trabeculoplasty; Ocular hypertension; Primary open-angle glaucoma; Blindness

\section{Introduction}

Glaucoma is a chronic, degenerative optic neuropathy which is characterized by changes in the optic disc and visual field loss. Intraocular pressure is considered the major risk factor for the progression of glaucomatous optic neuropathy involving the death of retinal ganglion cells and their axons. Selective Laser Trabeculoplasty (SLT) uses a 532nm frequency-doubled, q-switched neodymium, yttrium-aluminum-garnet laser that delivers a low-energy, large spot, it was designed to selectively target pigmented trabecular meshwork (TM) cells while sparing adjacent cells and tissues from thermal damage.

\section{Discussion}

Glaucoma is the second leading cause of blindness worldwide. Glaucoma affects more than 70 million people worldwide with approximately $10 \%$ being bilaterally blind, making it the leading cause of irreversible blindness in the world [1]. Meta-analysis of many studies showed that there was no statistically significant difference in IOP-reduction or treatment success between SLT and medical treatment [2].

As a first-line therapy for glaucoma, medications have many disadvantages and drawbacks. Patients have to accept their adverse effects, repeated application of medications and continuous medical costs. The potency of treatments may be undercut when people are non-compliant. The introduction to SLT, which uses a less severe energy to generate IOP-lowering effect without dangerous adverse reactions, has again brought up the question: can laser device treatments defeat eye drops as the main therapy for Glaucoma especially OAG? In the initial released research, SLT was used as the adjunct treatment to medication. Later several researches had recommended that SLT might be the main treatment for POAG or OHT [3]. Melamed et al. [4] found 40 in 45 eyes (89\%) which experienced SLT as the main treatment had an IOP loss of $5 \mathrm{mmHg}$ or more. Mean IOPreduction was $7.7 \pm 3.5 \mathrm{mmHg}(30 \%)$ at 18 months post-SLT. A potential, multicenter study by Mcllraith et al. [5] involved 100 eyes (61 patients) with recently clinically diagnosed POAG or OHT. IOP reduction was $8.3 \mathrm{mmHg}(31.0 \%)$ in the SLT team (74 eyes) in contrast to $7.7 \mathrm{mmHg}(30.6 \%)$ in the latanoprost team (26 eyes) $(\mathrm{P}=0.208$ and $\mathrm{P}=0.879)$. The amount of IOP reduction was mathematically considerably less in the latanoprost team than in the SLT team [5].

Selective laser trabeculoplasty (SLT) has been proven secure, well recognized, low-cost and very efficient at reducing intraocular pressure (IOP) as primary treatment in several types of glaucomas. The maintenance of trabecular meshwork (TM) structure and the confirmed effectiveness in decreasing IOP tend to make SLT a very affordable and secure alternative to argon laser trabeculoplasty (ALT). SLT may also be effective for situations of unsuccessful ALT and is a technique that may also be repeatable, compared with ALT. SLT is also a simple procedure for an ophthalmologist to learn and proceed. SLT has been confirmed to be efficient as main therapy and can be an effective 
adjunct therapy with medications for early stages of glaucoma. Furthermore, SLT can be regarded as a primary treatment choice for patients who cannot accept or who are noncompliant with their glaucoma medications, without disrupting the success of the forthcoming surgery [6].

\section{Conclusion}

SLT is easy to perform and well tolerated by patients and provides the benefits of ALT while using much less energy with less obvious harm to the TM. It seems to have comparative effectiveness to eye drops and to be a safe and effective glaucoma treatment without conformity threats or wide spread adverse reactions. Therefore, SLT is now considered the first line therapy for various types of glaucoma and can be an effective adjunct in the early types of glaucoma.

This work is licensed under Creative Commons Attribution 4.0 License DOI: $10.19080 /$ JOJO.2017.0.555630

\section{References}

1. Quigley HA, Broman AT (2006) The number of people with glaucoma worldwide in 2010 and 2020. Br J Ophthalmol 90(3): 262-267.

2. Leahy KE, White AJ (2015) Selective Laser Trabeculoplasty: Current Perspectives. Clinical Ophthalmology 9: 833-841.

3. Francis BA, Ianchulev T, Schofield JK, Minckler DS (2005) Selective laser trabeculoplasty as a replacement for medical therapy in open angle glaucoma. Am J Ophthalmol 140(3): 524-525.

4. Melamed S, Ben SGJ, Levkovitch VH (2003) Selective laser trabeculoplasty as primary treatment for open-angle glaucoma: a prospective, nonrandomized pilot study. Arch Ophthalmol 121(7): 957-960.

5. McIlraith I, Strasfeld M, Colev G, Hutnik CM (2006) Selective laser trabeculoplasty as initial and adjunctive treatment for open-angle glaucoma. J Glaucoma 15(2): 124-130.

6. Latina MA, Leon JM (2005) Selective laser trabeculoplasty. Ophthalmol Clin North Am 18(3): 409-419.

Your next submission with Juniper Publishers will reach you the below assets

- Quality Editorial service

- Swift Peer Review

- Reprints availability

- E-prints Service

- Manuscript Podcast for convenient understanding

- Global attainment for your research

- Manuscript accessibility in different formats

( Pdf, E-pub, Full Text, Audio)

- Unceasing customer service

Track the below URL for one-step submission https://juniperpublishers.com/online-submission.php 